\title{
PERKEMBANGAN AKUNTANSI BRUNEI DARUSSALAM DAN ANALISIS SHENANIGANS DALAM LAPORAN KEUANGANNYA
}

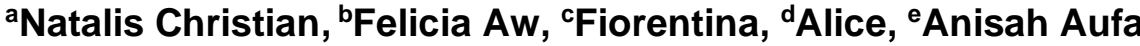 \\ abcde Universitas Internasional Batam \\ natalis.christian@uib.ac.id
}

\begin{abstract}
ABSTRAK
Brunei adalah satu-satunya negara berdaulat sepenuhnya di Kalimantan, sisa wilayah pulau dibagi antara negara Malaysia dan Indonesia. Menurut Dana Moneter Internasional (IMF), Brunei menempati urutan kelima di dunia berdasarkan produk domestik bruto per kapita pada paritas daya beli. Ada dua jenis Standar Akuntansi yang akan diadopsi di Brunei Darussalam, yaitu Standar Pelaporan Keuangan Internasional (IFRS) dan Standar Akuntansi Brunei Darussalam (BDAS) yang dikeluarkan oleh BDASC untuk entitas lain yang tidak memiliki akuntabilitas publik (entitas kepentingan non-publik). Dengan analisis yang penulis lakukan berdasarkan laporan tahunan dan laporan keuangan dengan memakai objek Bank Islam Brunei Darussalam (BIBD) selama 5 tahun terakhir, hasil analisa menunjukkan bahwa perusahaan tidak melakukan praktik Shenanigans 1, Shenanigans 2, Shenanigans 4, Shenanigans 5, Shenanigans 6, Shenanigans 7. Bank Islam Brunei Darussalam (BIBD) melakukan teknik Shenanigans 3 dalam pencatatan laporan keuangannya tanpa pengaruh yang signifikan (jumlah yang kecil) sehingga laporan keuangan masih wajar dan tidak merugikan pihak yang bersangkutan.
\end{abstract}

Kata Kunci: Brunei Darussalam, Perkembangan Akuntansi, Teknik Shenanigans.

\begin{abstract}
Brunei is the only fully sovereign state on Borneo, the rest of the island is divided between Malaysia and Indonesia. According to the International Monetary Fund (IMF), Brunei ranks fifth in the world based on gross domestic product per capita at purchasing power parity. There are two types of Accounting Standards that will be adopted in Brunei Darussalam, namely International Financial Reporting Standards (IFRS) and Brunei Darussalam Accounting Standards (BDAS) issued by BDASC for other entities that do not have public accountability (entities of non-public interest).The analysis conducted based on the Islamic Bank of Brunei Darussalam (BIBD) publication reports for the last 5 years. The results show that between financial shenanigans 1 to 7 , the company applies the Shenanigans 3 technique in recording its financial statements without any significant effect (small amount) so that the financial statements are still reasonable and do not harm the parties concerned.
\end{abstract}

Keywords: Brunei Darussalam, Accounting Development, Shenanigans Technique.

\section{PENDAHULUAN}

Kasus penipuan laporan keuangan dimulai dengan munculnya kasus perusahaan besar di Eropa seperti Enron dan Worldcom (Asim \& Ismail, 2019). Perusahaan tersebut melakukan manipulasi finansial guna meningkatkan kepercayaan kreditur, pemegang saham serta masyarakat terhadap perusahaan. Enron telah melakukan aksi Shenanigans dimana dapat dilihat dari beberapa gejala sebelum terungkapnya kasus manipulasi misalnya peningkatan secara pesat tingkat perusahaan Enron pada Forbes Fortune dalam waktu yang singkat, serta adanya kejangkalan pada laporan keuangan dimana Enron mencatat pendapatan yang tinggi daripada perusahaan lainnya namun memiliki laba bersih yang lebih 
rendah dibandingkan perusahaan lainnya. Dari kejanggalan tersebut, terbukti Enron telah melakukan aksi Shenanigans dan bangkrut. Namun bangkrutnya Enron menyebabkan kerugian yang sangalah besar pada dunia ekonomi. Maka dari itu, muncullah berbagai peraturan untuk memperketat informasi yang dilaporkan oleh perusahaan supaya mengurangi tingkat terjadinya penipuan seperti ini.

Selain memperbanyak peraturan, muncul pula akuntansi forensik yang mempelajari mengenai praktik akuntansi dan kemampuan investigasi untuk membantu dalam masalah legal dan mengaplikasikan pengetahuan khusus terhadap bukti transaksi ekonomi serta memberikan analisis akuntansi yang dapat mengatasi masalah dari perusahaan (Osunwole, 2020). Namun, peraturan prinsip akuntansi setiap negara berbeda sehingga perlu adanya kemampuan untuk beradaptasi dengan peraturan dari negara tertentu ketika menginvestigasi laporan perusahaan luar negeri. Selain daripada itu, dikenali pula financial shenanigans sebagai pedoman atas teknik-teknik manipulasi laba yang dapat dilakukan oleh perusahaan.

Secara garis besar, ada 7 manipulasi laba shenanigans yang dipelajari oleh (Schilit, 2010b) yaitu mencatat pendapatan terlalu cepat, mencatat pendapatan palsu, meningkatkan pendapatan menggunakan aktivitas satu kali atau aktivitas tidak berkelanjutan, mengalihkan beban saat ini ke periode berikutnya, menggunakan teknik lain untuk menyembunyikan beban atau kerugian, mengalihkan pendapatan saat ini ke periode berikutnya, dan mengalihkan beban masa depan ke periode lebih awal.

\section{TINJAUAN PUSTAKA}

Brunei Darussalam terletak di bagian barat laut pulau Kalimantan, menghadap ke Laut Cina Selatan dan dikelilingi oleh Malaysia Timur. Minyak dan gas telah menjadi tulang punggung perekonomian negara sejak ditemukan pada tahun 1929. Kebudayaan negara itu berakar kuat pada asal-usul Melayu. Ini tercermin dalam bahasa, arsitektur, upacara, dan adat istiadatnya. Komitmen Brunei untuk kemakmuran yang berkelanjutan dan ekonomi makro yang stabil digarisbawahi oleh Wawasan 2035, visi nasional pemerintahnya. Wawasan 2035 menyediakan promosi investasi baik di industri hilir dan kelompok ekonomi di luar industri minyak dan gas. Ini terdiri dari 13 strategi yang meliputi pendidikan, stabilitas politik dan keamanan, pengembangan kelembagaan, pengembangan bisnis lokal, infrastruktur, jaminan sosial, dan lingkungan (Eye on asian, 2021).

\section{Brunei Darussalam}

Pada 1 Agustus 2011, Brunei Darussalam melakukan penegakan Accounting Standard Order (ASO) 2010 dengan mendirikan Brunei Darussalam Accounting Standar Council (BDASC). BDASC memiliki tugas atas pengeluaran standar akuntansi unyuk diaplikasikan pada perusahaan dan badan-badan yang ada di Brunei Darussalam. Penegakan Standar Akuntansi Orde 2010 tersebut telah mendapatkan persetujuan dari Yang Mulia Sultan Brunei Darussalam yang diumumkan melalui Kementerian Keuangan (BDASC, 2020).

Accounting Standar Orde ini berfungsi untuk pengawasan praktek serta profesi jasa audit akuntansi oleh akuntan publik atas kepatuhan terhadap standar dan persyaratan yang berlaku. Supaya setiap praktek audit dapat dipercayai dan memberikan kepantasan laporan perusahaan atas kebenarannya. Selain daripada itu juga bertugas untuk menyusun standar akuntansi yang berlaku bagi perusahaan dan badan hukum di negaranya.

Ada dua jenis Standar Akuntansi yang akan diadopsi di Brunei Darussalam:

i. Standar Pelaporan Keuangan Internasional (IFRS) yang dikeluarkan oleh Dewan Standar Akuntansi Internasional (IASB) untuk semua entitas yang memiliki akuntabilitas publik (entitas kepentingan publik) di Brunei Darussalam efektif mulai 1 Januari 2014.

IFRS adalah seperangkat standar akuntansi yang dikembangkan oleh Dewan Standar Akuntansi Internasional (IASB) dan menjadi standar global untuk penyusunan laporan keuangan bertujuan umum. 
ii. Standar Akuntansi Brunei Darussalam (BDAS) yang dikeluarkan oleh BDASC untuk entitas lain yang tidak memiliki akuntabilitas publik (entitas kepentingan nonpublik) di Brunei Darussalam berlaku efektif mulai 1 Januari 2018.

\section{Indonesia}

Indonesia mengikuti standard akuntansi yang ditetapkan oleh Pernyataan Standar Akuntansi Keuangan (PSAK), dibuat oleh Dewan Standar Akuntansi Keuangan (DSAK). Sistem akuntansi ini diangkat dari standar keuangan sesuai dengan International Accounting Standards Board (IASB). Kegiatan ekspor dan impor yang semakin kompleks, dan juga semakin berkembangnya perusahaan asing di indonesia, menyebabkan standar PSAK saat ini hendak dipersatukan. Tujuannya membuat standar akuntansi di Indonesia serupa dengan standar akuntansi di dunia internasional (Zsazya, 2020).

Indonesia telah menggunakan International Financial reporting standards (IFRS) untuk penulisan laporan keuangannya. IFRS telah menjadi patokan dasar untuk menyamakan pembuatan laporan keuangan dunia. IFRS juga telah diterapkan oleh berbagai negara maju serta berkembang. Dengan adanya IFRS, sistem pencatatan laporan keuangan akan serupa dengan Negara lain, dan hal ini juga tentu memudahkan pencatatan laporan keuangan perusahaan asing di Indonesia.

IAI yang berdiri sejak 23 Desember 1957, bertindak sebagai badan pengaturan dan pembinaan akuntansi di Indonesia dengan pengawasan Departemen Keuangan. Penyusuanan SAK dan SPAP dilakukan oleh pihak IAI. Dulunya, sistem tata buku Belanda digunakan oleh Indonesia. Kemudian, setelah kemerdekaan menggunakan pola Amerika tahun 2005. Sejak Januari 1995, standar IASC mulai berlaku dan telah tertulis dalam PSAK (Zsazya, 2020).

\section{Brunei Darussalam Accounting Standards - Non Public Interest Entities (BDAS- NONPIE).}

Untuk entitas yang memenuhi syarat berdasarkan kerangka kerja NON-PIE untuk menyusun dan menyajikan laporan keuangannya sesuai dengan BDAS NON-PIE, satu set lengkap laporan keuangan terpisah untuk entitas tersebut mencakup neraca, laporan laba rugi, kebijakan akuntansi dan catatan penjelasan, laporan arus kas.

BDAS NON-PIE tidak digunakan dalam pembuatan serta penyajian laporan keuangan konsolidasian (BDASC, 2020). Setiap item material harus disajikan secara terpisah dalam laporan keuangan. Aset dan kewajiban biasanya tidak boleh saling hapus dalam laporan keuangan. Komparatif informasi harus dimasukkan dalam informasi narasi dan deskripsi pada saat itu berhubungan dengan pengertian mengenai laporan keuangan masa sekarang.

Namun, beberapa penggantian kerugian diperlukan atau diizinkan dalam keadaan luar biasa, seperti diamanatkan oleh BDAS NON-PIE. Pengimbangan juga dapat terjadi di mana keuntungan, kerugian dan biaya terkait yang timbul dari transaksi yang sama atau serupa tidak material.

\section{Perbedaan signifikan antara BDAS dan IFRS}

IFRS menyediakan pelaporan detail yang komprehensif untuk masing-masing pemangku kepentingan entitas kepentingan publik seperti pemerintah, regulator, dan lainnya. Di sisi lain, BDAS kurang detail dan kompleks karena secara khusus diperkenalkan untuk memfasilitasi konsistensi. dalam pelaporan keuangan non-PIE di Brunei Darussalam (BDASC, 2020).

Dengan mengadopsi IFRS, entitas dapat menyajikan laporan keuangannya dengan komparabilitas, kualitas, transparansi, dan pemahaman yang lebih baik. Ini akan membantu mereka menarik investasi asing, memperluas bisnis dan meningkatkan posisi pasar mereka. Karena ada lebih dari 100 negara dan tumbuh menyatu dengan atau mengadopsi IFRS, entitas juga dapat membuat platform akuntansi yang seragam dengan dunia.

Penerapan penuh IFRS berlaku efektif sejak 1 Januari 2014. Ini akan berlaku untuk perusahaan akuntabel publik untuk periode akun mulai 1 Januari 2014. Beberapa perusahaan lintas Negara yang tergolong besar sudah mulai menggunakan IFRS untuk anak perusahaan 
/ cabang luar negerinya. Semua perusahaan akuntabel publik seperti bank, lembaga keuangan, asuransi dan perusahaan takaful diwajibkan untuk mengadopsi IFRS penuh. Untuk Badan Hukum yang disebutkan dalam skedul ASO 2010, Otoritas akan memutuskan Standar yang sesuai untuk mereka adopsi (Primasanti, 2014).

\section{Balance sheet}

Entitas harus menentukan, berdasarkan sifat operasinya, apakah akan menyajikan atau tidak aset dan kewajiban lancar serta tidak lancar dalam bagian berbeda dalam pelaporan neraca. Jika perusahaan tidak membedakannya, aset dan liabilitas harus dilaporkan sesuai dengan urutan likuiditasnya dan entitas harus mengungkapkannya masingmasing aset dan liabilitas yang disatukan dengan nilai yang diharapkan akan diselesaikan sebelum dan sesudahnya.

\section{Income statement}

Pelaporan laba rugi harus menyertakan, pendapatan, biaya keuangan, beban pajak dan untung atau rugi dalam periode tertentu. Seluruh pos penerimaan dan biaya yang diakui dalam periode tertentu dimasukkan ke penentuan laba rugi sesuai periode kecuali BDAS NON-PIE mensyaratkan atau mengizinkan sebaliknya (BDASC, 2020).

\section{Changes in Equity}

Entitas harus menyajikan perubahan ekuitas baik dalam catatan keuangan laporan keuangan atau sebagai komponen terpisah dalam laporan keuangan. Perubahan dalam ekuitas harus mencakup beberapa hal yaitu keuntungan atau kerugian untuk periode tersebut, sejumlah penerimaan dan pembiayaan, laba atau kerugian yang sebagaimana disyaratkan oleh BDAS NON-PIE yang diakui langsung dalam ekuitas.

\section{Kebijakan akuntansi dan catatan penjelasan}

Catatan atas laporan keuangan harus memberikan informasi mengenai dasar pembentukan laporan keuangan, serta kebijakan akuntansi tersendiri yang ditentukan dan digunakan untuk signifikan transaksi dan peristiwa. Selain itu, harus memberikan informasi yang diperlukan oleh BDAS NON-PIE yang tidak terdapat pada tempat lainnya dalam pelaporan keuangan. Informasi tambahan yang disajikan yang diperlukan sesuai presentasi yang tepat.

Catatan atas laporan keuangan dituntus untuk disajikan secara berurutan. Masingmasing item di pelaporan neraca dan laporan laba rugi harus direferensikan silang dengan informasi tertentu dalam pencatatan.

Kebijakan akuntansi BDAS dari catatan atas laporan keuangan dituntut untuk menjelaskan sebagaimana laporan keuangan telah dibentuk sesuai dengan BDAS NON-PIE dan kriteria entitas yang memenuhi syarat untuk menerapkan BDASNON-PIE. Dasar pengukuran yang dipakai dalam penyusunan laporan keuangan serta kebijakan akuntansi khusus juga dituntut untuk dijelaskan untuk pemahaman yang tepat pada laporan keuangan.

\section{METODE PENELITIAN}

Penelitian ini menganalisis pelaporan laporan keuangan dari perusahaan Tokio Marine Insurance Singapore Ltd yang memiliki cabang di negara Brunei Darussalam. Laporan keuangan yang digunakan merupakan laporan keuangan pada tahun 2018 yang dipublikasikan pada website perusahaan. Pemilihan sampel ini dipilih karena keterbatasan atas laporan keuangan yang dipublikasikan oleh perusahaan yang menggunakan standar IFRS di negara Brunei. Selain itu, analisis financial shenanigans menggunakan laporan keuangan dari Bank Islam Brunei Darussalam (BIBD) yang merupakan bank terbesar di Brunei Darussalam dan merupakan perusahaan terbuka dengan memiliki kelengkapan laporan keuangan selama lima tahun. Keterbatasan dari sampel penelitian terjadi karena 
Brunei Darussalam belum memiliki bursa efek sehingga meningkatkan kesulitan dalam menemukan publikasi laporan keuangan perusahaan yang sesuai.

Penelitian ini menggunakan dua metode dalam pengumpulan informasi, yakni metode penelitian kualitatif dan kuantitatif. Penelitian kualitatif didefinisikan sebagai model penelitian dimana informasi yang di kumpulkan tidak didapatkan melalui prosedur statistik atau bentuk angka. Jenis penelitian ini biasanya memiliki tujuan untuk menafsirkan obyek penelitian secara mendalam dan menyeluruh. Metode penelitian membuat deskripsi secara sistematis, bedasarkan pada fakta.

Penelitian kuantitatif adalah penelitian yang dibuat menggunakan data dari angkaangka dan dianalisis menggunakan statistik. Creswell (2002) mencatat bahwa penelitian kuantitatif adalah proses mengumpulkan, menganalisis, menafsirkan, dan menulis hasil penelitian. Penelitian kuantitatif biasanya dilakukan karena para peneliti membutuhkan data numerik untuk menjawab pertanyaan atas penelitannya tersebut. Metode kuantitatif biasanya menggunakan data yang diukur berdasarkan kejadian nyata secara objektif sehingga hasil penelitian lebih bermutu karena objektivitas yang terungkap dalam data yang telah dikumpulkan (Williams, 2007).

\section{HASIL DAN PEMBAHASAN}

\section{Financial reporting IFRS Brunei Vs IFRS Indonesia \\ 1. Statement Of Financial Position}

Adanya akun available for sale financial assets pada negara brunei yang menurut IAS 39 mengartikannya sebagai aset finansial non-derivatif yang ditetapkan pada pencatatan di awal sebagai persediaan untuk dijual atau lainnya yang tidak tergolong dalam pinjaman yang diberikan dan piutang, dimiliki hingga jatuh tempo investasi atau aset fiansial yang diukur dengan nilai wajar melalui laba rugi (BDASC, 2020).

\section{Gambar 1. \\ Statement Of Financial Position}

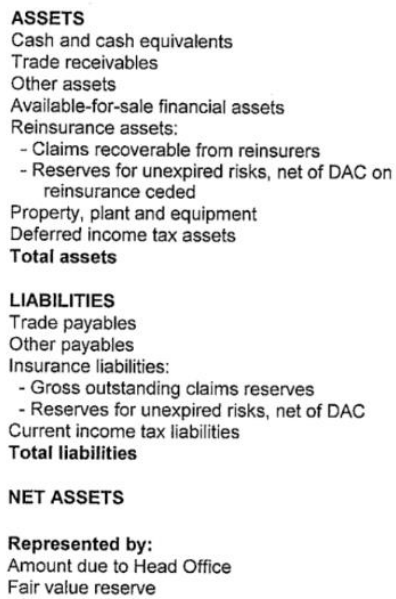

Sumber: Tokio Marine Insurance Singapore Ltd, Brunei Darussalam Branch Audited Financial Statements and Other Financial Information (31st December 2018)

Kemudian, pada negara brunei laporan posisi keuangan hanya terbagi atas aset dan liabilitas dan menggunakan pengurangan dari liabilitas untuk mendapatkan Net assets dimana ini sangat berbeda dengan regulasi laporan di indonesia yang memisahkan aset dan liabilitas serta adanya ekuitas.

Pada laporan brunei ada juga represented by amount due to head office dimana hal ini adalah adalah jumlah pinjaman dari perusahaan cabang terhadap perusahaan pusat. Fair 
value reserve adalah sebuah cadangan untuk melihat perubahan pada nilai wajar sebuah aset ketika masih diakui dalam laporan keuangan entitas. Akun ini adalah akun ekuitas bagi perusahaan Brunei.

\section{Statement Of Profit or Loss}

Pada laporan keuangan Indonesia akun dari underwriting revenues dan expenses lebih terincikan daripada laporan keuangan Brunei namun hal ini bisa saja terjadi dikarenakan tidak ada regulasi yang mewajibkan untuk merincikan secara detail. Untuk laporan keuangan di Indonesia ada pemisahan antara laba dengan laba lainnya atau other income dan juga beban biaya namun pada laporan keuangan Brunei akun tersebut masuk ke dalam pembagian revenue dan expenses. Pada laporan keuangan indonesia ada akun yang merupakan net laba untuk diatribusikan kepada pemilik entitas induk serta $\mathrm{NCl}$ sedangkan pada laporan keuangan Brunei tidak ada hal demikian.

\section{General Insurance Revenue Account}

General insurance revenue account hanya ada pada laporan keuangan Brunei dimana laporan ini menunjukan asuransi yang ditawarkan dari perusahaan yang harus disediakan oleh perusahaan asuransi berdasarkan regulasi IRDA (Insurance Regulatory and Development Authority) tahun 2002. Laporan ini mencatat income dan expense dari bisnis tersebut serta laba/rufi yang di transfer ke akun laba dan rugi. Sehingga laporan ini mengindikasikan cara perhitungan akun underwriting profit yang ada pada laporan laba rugi sebelumnya.

\section{Gambar 2. \\ General Insurance Revenue Account}

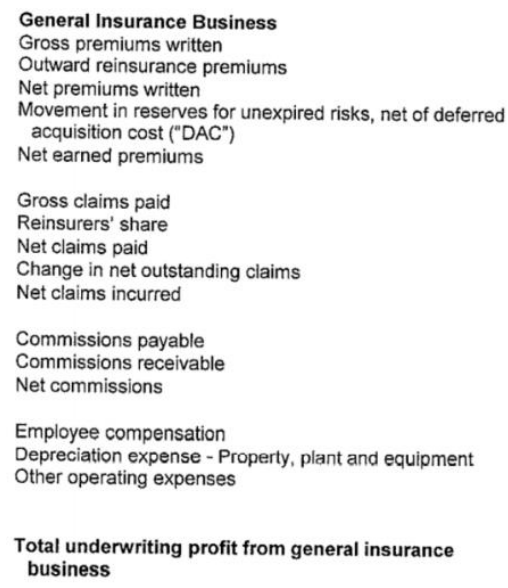

Sumber: Tokio Marine Insurance Singapore Ltd, Brunei Darussalam Branch Audited Financial Statements and Other Financial Information (31st December 2018)

\section{Statement Of Cash Flow}

Pada laporan brunei, ada akun trade receivables namun pada laporan indonesia piutang tersebut dipisahkan menjadi premi, reasuransi dan lainnya. Serta dalam laporan brunei ada akun due to head office yang dikarenakan merupakan cabang perusahaan dari Singapura sedangkan pada Indonesia tidak memiliki akun tersebut. Untuk laporan dari Brunei ada pengurangan pembayaran income tax sebelum menjumlahkan kas yang didapatkan dari aktivitas operasional.

\section{Gambar 3. Statement Of Cash Flow}




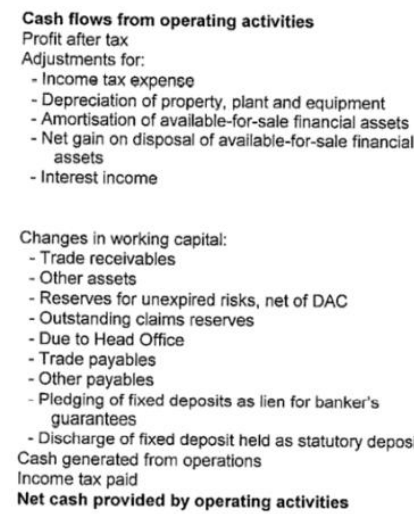

Cash flows from investing activities

Additions to property, plant and equipment

Dispose of available-for-sale financial asse

Cash flows from financing activity

Transfer to Head Office

Net cash used in financing activity

Net increase in cash and cash equivalents

Cash and cash equivalents at beginning of financial year Cash and cash equivalents at end of financial year

\section{Sumber: Tokio Marine Insurance Singapore Ltd, Brunei Darussalam Branch Audited Financial Statements and Other Financial Information (31st December 2018)}

Pada laporan keuangan dari negara brunei arus kas dari aktivitas investasi menggunakan penamaan yang berbeda dengan indonesia dimana penambahan PPE di indonesia menggunakan akun investment properties. Pembelian aset keuangan yang dapat di jual dan pembuangan aset keuangan tersebut di indonesia tidak memiliki akun tersebut melainkan hanya memiliki pembuangan dan akuisisi property dan equipment.

Pada aktivitas financing, perusahaan di brunei hanya memiliki 1 akun dimana perusahaan cabang harus mentransfer sejumlah uang kepada perusahaan pusat atau induk sedangkan dalam laporan indonesia kegiatan ini dirincikan modal disetor kepada anak perusahaan, pembayaran dividen baik perusahaan induk maupun anak perusahaan.

\section{Analisis Financial shenanigans}

Financial shenanigans merupakan suatu perlakuan dari pihak manajemen perusahaan yang bertujuan untuk meningkatkan kinerja nilai perusahaan dengan cara yang tidak benar sehingga dapat memberikan informasi salah kepada investor ataupun pengguna laporan keuangan. Sehingga para pengguna laporan keuangan pun termanipulasi oleh angka yang tertera dalam laporan seperti dari sisi pendapatan, arus kas maupun posisi dalam neraca saldo yang terlihat sangat meyakinkan kinerja perusahaan sangat baik.

Dalam analisis financial shenanigans, kami memilih Bank Islam Brunei Darussalam (BIBD) sebagai objek penelitian. BIBD, bank terbesar dan lembaga keuangan Islam unggulan Brunei Darussalam, dibentuk pada tahun 2005 dengan menyatukan Bank Islam Brunei dan Bank Pembangunan Islam Brunei. Sebagai bank Islam andalan Brunei dan penyedia layanan keuangan terbesar, dengan sekitar 900 karyawan dan aset yang dikelola senilai B \$10,7 miliar.

Untuk meningkatkan pendapatan periode saat ini, manajemen harus mendorong lebih banyak pendapatan atau keuntungan ke periode saat ini atau mengalihkan biaya ke periode berikutnya. Kejahatan di bawah ini dapat dikategorikan dalam:

\section{Shenanigans 1 - Mencatat Pendapatan Terlalu Cepat}

Shenanigans 1 menjelaskan berbagai cara yang digunakan manajemen untuk mempercepat pendapatan ke periode sebelumnya dan bagaimana investor melihat tandatanda pelanggaran. Terdapat empat cara pendapatan yang terlalu dini menurut (Schilit, 2010b), yaitu mencatat pendapatan yang diterima dimuka sebagai pendapatan, mencatat pendapatan ketika produk atau jasa belum dikirim atau pelanggan belum menerimanya, mencatat pendapatan meski pelanggan tidak diwajibkan untuk bayar, dan menjual kepada pihak terafiliasi.

Bagi perusahaan untuk mengakui pendapatan yang menggambarkan pengalihan barang atau jasa kepada pelanggan dalam jumlah yang mencerminkan pertimbangan yang diharapkan perusahaan berhak atas imbalan barang atau potongan tersebut. Standar ini juga akan menghasilkan pengungkapan yang lebih baik tentang pendapatan, memberikan panduan untuk transaksi yang sebelumnya tidak ditangani secara komprehensif, dan 
meningkatkan panduan untuk pengaturan multi-elemen. Berdasarkan laporan keuangan selama 5 tahun terakhir, dibandingkan dengan tahun sebelumnya tidak ditemukan adanya pencatatan pendapatan yang terlalu cepat yang artinya Bank Islam Brunei Darussalam (BIBD) tidak melakukan shenanigans 1.

\section{Shenanigans 2 - Mencatat Pendapatan Palsu}

Perusahaan biasanya melaporkan pendapatan palsu dengan mencatat pendapatan dengan salah satu dari empat cara yang tidak tepat (Schilit, 2010c) yaitu dari transaksi yang tidak memiliki substansi ekonomi, transaksi yang tidak memiliki proses yang wajar, pada penerimaan dari transaksi yang tidak menghasilkan pendapatan, dari transaksi yang sesuai tetapi dalam jumlah yang meningkat.

Pendapatan provisi dan komisi bersih Grup dan Bank seluruhnya berasal dari aset dan liabilitas keuangan yang diukur dengan biaya perolehan diamortisasi. Pendapatan provisi dan komisi bersih di atas tidak termasuk dalam menentukan tingkat imbal hasil efektif atas aset keuangan dan liabilitas keuangan yang tidak diukur pada nilai wajar melalui laporan laba rugi, tetapi termasuk pendapatan dan beban lain yang terkait dengan aset keuangan dan liabilitas keuangan tersebut.

Dengan pengakuan pendapatan dan pembiayaan yang dilakukan oleh pihak Bank Islam Brunei Darussalam (BIBD), dimana pendapatan dan pembiayaan yang dihitung dengan menggunakan metode imbal hasil efektif, biaya perolehan diamortisasi (sesuai dengan kebijakan akuntansi yang ditetapkan). Setiap pendapatan yang dicatat oleh BIBD diberikan penjelasan yang detail dalam catatan atas pelaporannya, setiap akun dijabarkan dengan jelas pendapatan bersumber dari mana dan metode yang digunakan. Maka berdasarkan hasil analisis, Bank Islam Brunei Darussalam (BIBD) tidak melakukan teknik "Shenanigans 2 Mencatat Pendapatan Palsu".

\section{Shenanigans 3 - Meningkatkan Pendapatan Menggunakan Aktivitas Satu Kali atau Aktivitas Tidak Berkelanjutan}

Meningkatkan laba dengan trik akuntansi dan keuntungan satu kali dapat membuat manajer senang, tetapi investor dan pemberi pinjaman yang mengandalkan laporan keuangan yang menyesatkan tidak selalu senang. Laporan semacam itu sering kali menampilkan citra perusahaan yang sehat padahal kenyataannya justru sebaliknya (Schilit, 2010a). Hal ini dapat dilakukan dengan meningkatkan keuntungan dengan menjual aset yang dinilai terlalu rendah, termasuk pendapatan atau keuntungan investasi sebagai bagian dari pendapatan, melaporkan pendapatan atau keuntungan investasi sebagai pengurangan biaya operasi, dan menciptakan pendapatan dengan reklasifikasi akun neraca.

Berdasarkan data yang didapatkan melalui laporan keuangan dalam 5 tahun terakhir, Bank Islam Brunei Darussalam (BIBD) mencatat Fair value gain on investments designated at fair value through profit and loss, Gain (loss) from sale of investment securities at fair value through other comprehensive income, dan Gain from sale of investment securities at amortised cost dalam pelaporan pendapatan di catatan Gain/(loss) from derivative and investments. Jika dikaitkan, ini berhubungan dengan perlakuan Shenanigans 3, yaitu tindakan mencatat pendapatan atau keuntungan investasi sebagai bagian dari pendapatan. Pencatatan pendapatan atas investasi ini dilakukan oleh Bank Islam Brunei Darussalam dalam laporan keuangan yang diamati selama 5 tahun.

Profits from financing, leasing and investments yang dicatat pada laporan jika dibandingkan dengan pencatatan pendapatan atas investasi sangatlah berbeda jauh. Misalnya pencatatan Profits from financing, leasing and investments tahun 2020 sebesar (B\$'000) 315,806 dan Gain/(loss) from derivative and investments tahun 2020 sebesar (B\$000) 36,592. Pendapatan atas investasi yang dicatat tidak mempengaruhi angka pendapatan secara signifikan, hanya bagian kecil dari pendapatan saja. Dengan hasil analisis, ditarik kesimpulan bahwa Bank Islam Brunei Darussalam (BIBD) melakukan teknik Shenanigans 3 dalam pencatatan laporan keuangannya tanpa pengaruh yang signifikan (jumlah yang kecil) sehingga laporan keuangan masih wajar dan tidak merugikan pihak yang bersangkutan. 


\section{Shenanigans 4 - Mengalihkan Beban Saat Ini ke Periode Berikutnya}

Bagi perusahaan untuk meningkatkan laba pada laporan keuangan dapat dilakukan dengan mudah dengan menurunkan beban biaya periode tersebut. Sehingga manajemen dapat memindahkan beban tersebut ke periode berikutnya supaya kinerja perusahaan meningkat bersama peningkatan laba yang telah dimanipulasinya. Cara manipulasi beban ini dapat dijelaskan dengan sederhana dalam 2 langkah dimana langkah pertama adalah pada saat suatu pengakuan beban yang belum didapatkan manfaatnya atau manfaat untuk masa depan perusahaan maka dicatat ke dalam neraca sado sebagai aset. Kemudian langkah kedua adalah pada saat manfaat sudah dirasakan atau diterima oleh perusahaan kemudian aset tersebut pindah ke laporan laba rugi sebagai beban perusahaan. Letak kecurangan adalah pada waktu pengakuan sebagai beban perusahaan. Hal ini dapat dilakukan dengan beberapa teknik menurut Schilit (2010), yaitu mengkapitalisasi beban operasional secara tidak benar, telat amortisasi biaya, tidak mencatat aset yang nilainya telah jatuh (impaired asset), tidak mencatat beban atas piutang tak tertagih dan penurunan nilai investasi.

Berdasarkan data laporan keuangan 5 tahun terakhir, dari laporan neraca saldo dan laporan laba rugi tidak menimbulkan kecurigaan atas perlakuan shenanigans 4 . Hal tersebut disimpulkan berdasarkan setiap aset yang dirincikan dalam catatan atas laporan keuangan dan laporan laba rugi yang tidak menunjukan adanya penurunan beban biaya secara signifikan, kesalahan dalam pencatatan nilai aset, amortisasi biaya juga tidak ada tanda keterlambatan. Selain dari itu, tidak ada tanda peningkatan laba secara drastis dan juga dari laporan arus kas tidak ada penurunan arus kas dari kegiatan operasional. Maka dari itu laporan keuangan Bank Islam Brunei Darussalam Berhad tidak menerapkan perlakuan shenanigans 4 .

\section{Shenanigans 5 - Menggunakan Teknik Lain untuk Menyembunyikan Beban atau Kerugian}

Perusahaan akan melakukan segala hal untuk meningkatkan kinerja perusahaannya demi pandangan dari masyarakat, kreditur dan pemegang saham untuk percaya dengan kemampuan perusahaan. Selain mengalihkan beban ke periode selanjutnya, perusahaan dapat menyembunyikan beban tersebut agar kinerja perusahaan terlihat lebih memungkinkan walaupun hal tersebut dapat meningkatkan beban pajak. Tetapi tetap saja tujuan perusahaan adalah demi meningkatkan nilai perusahaan daripada menurunkan beban pajak.

Beban yang disembunyikan merupakan beban yang memiliki jangka waktu pendek sehingga lebih fokus pada pemeriksaan pada laporan laba rugi daripada menginvestigasi dari bagian aset laporan nerasa saldo. Ada beberapa teknik yang dapat dilakukan perusahaan untuk menyembunyikan beban yaitu dengan tidak mencatat beban dari transaksi yang terjadi, gagal mencatat beban untuk akrual yang diperlukan atau membalikan beban periode sebelumnya, gagal mencatat atau mengurangi beban dengan menggunakan asumsi akuntansi agresif, dan mengurangi beban dengan melepaskan cadangan atau reserves palsu dari beban sebelumnya (Schilit, 2010c).

Dari data laporan keuangan 5 tahun terakhir, tidak ada tanda-tanda adanya penerapan shenanigans 5 seperti kredit dari vendor yang tidak biasa, penurunan akun reserves ataupun perubahan asumsi mengenai leasing. Maka dari itu, dapat disimpulkan Bank Islam Brunei Darussalam Berhad pada 5 tahun terakhir tidak ada tanda-tanda terjadinya shenanigans 5 dengan menyembunyikan beban atau kerugian.

\section{Shenanigans 6 - Mengalihkan Pendapatan Saat Ini ke Periode Berikutnya}

Ketika pendapatan sebuah perusahaan meningkat secara signifikan melebihi estimasinya, memungkinkan perusahaan untuk tidak melaporkan sebagian dari pendapatannya untuk diahlikan ke masa depan ketika pendapatan perusahaan sedang rendah dengan tujuan agar pendapatan pada laporan keuangan perusahaan terlihat stabil dan baik di mata publik (Schilit, 2010a). 
Pengalihan pendapatan ke periode berikutnya dapat dilakukan dengan berbagai teknik yaitu membuat cadangan pendapatan sekarang dan mencatatnya ke pendapat masa depan dan menahan pendapatan pada periode sebelum akuisisi dan dilepaskan setelah akuisisi.

Berdasarkan data yang didapatkan melalui laporan keuangan dalam 5 tahun terakhir, Bank Islam Brunei Darussalam (BIBD), dapat diketahui bahwa pendapatan yang tercatat terus meningkat dari tahun ke tahun menunjukan pendapatan perusahaan yang stabil. Meskipun memiliki pendapatan yang stabil dalam periode yang panjang merupakan salah satu indikator terjadinya Shenanigans 6. Dapat dilihat dari other reserves Bank Islam Brunei Darussalam (BIBD) dimana other reserves dari tahun 2015-2016 meningkat dari B $\$ 000182.341 \mathrm{ke}$ 213.711, namun pada tahun 2017, other reserves BIBD menurun secara signifikan ke $\mathrm{B} \$ 000$ 84.583 dimana dikarenakan tingginya dividen yang dibayar meningkat secara sebagian. Kemudian pada tahun 2018, other reserves BIBD meningkat secara signifikan menjadi B $\$ 000$ 142.666. Kemudian pada tahun 2019, other reserves meningkat lagi menjadi $B \$ 000200.937$. Penurunan tersebut dapat dikarenakan oleh adanya interim dividend yang dibayarkan pada tahun 2017, sehingga other reserves menurun secara signifikan. Adanya interim dividend yang dibayarkan pada tahun 2017 menyebabkan final dividend periode 2017 yang dibayarkan pada 2018 berkurang sehingga terjadinya kenaikan other reserves secara signifikan pada tahun 2018. Rincian reserves pada Bank Islam Brunei Darussalam (BIBD) dirincikan secara jelas pada laporan tahunan perusahaan. Maka berdasarkan hasil analisis, Bank Islam Brunei Darussalam (BIBD) tidak melakukan teknik "Shenanigans 6 - Mengalihkan Pendapatan Saat Ini ke Periode Berikutnya".

\section{Shenanigans 7 - Mengalihkan Beban Masa Depan ke Periode Lebih Awal}

Ketika perusahaan memiliki kinerja perusahaan yang rendah, maka perusahaan dapat mengahlikan beban masa depan ke periode yang lebih awal dengan tujuan pendapatan perusahaan masa depan lebih baik karena beban pada periode tersebut telah dibebankan pada periode sebelumnya (Schilit, 2010a). Pengalihan beban masa depan ke periode yang lebih awal biasanya dilakukan dengan menginflasikan nominal pada biaya khusus (special charge) dimana termasuk beban operasi masa depan, menghapus biaya R\&D in-process pada saat akuisisi, mempercepat biaya diskresioner masa depan ke periode sekarang.

Berdasarkan data yang didapatkan melalui laporan keuangan dalam 5 tahun terakhir, Bank Islam Brunei Darussalam (BIBD), dapat diketahui bahwa beban Bank Islam Brunei Darussalam (BIBD) adalah beban gaji, periklanan, sewa, depresiasi, beban perkantoran, biaya manajemen dan beban lainnya. Bila dibandingkan beban-beban tersebut dari periode 2015-2019, dapat diketahui bahwa tidak ada perubahan yang signifikan pada beban perusahaan dari tahun ke tahun. Sebagai contoh, beban depresiasi property, peralatan, dan investasi dimana dari tahun 2015 sebesar $\mathrm{B} \$ 000$ 24.597, menjadi $\mathrm{B} \$ 00022.478$ pada tahun 2016, kemudian pada tahun 2017, beban depresiasinya sebesar $\mathrm{B} \$ 00020.067$. Pada tahun 2018 , beban depresiasi BIBD sebesar $B \$(000)$ 17.754. Penurunan dalam nominal yang tidak signifikan disebabkan oleh berkurangnya properti dan peralatan BIBD pada tahun 2018 dimana terbukti dari laporan neraca perusahaan. Tidak adanya perubahan signifikan pada beban perusahaan dari tahun ke tahun. Maka berdasarkan hasil analisis, Bank Islam Brunei Darussalam (BIBD) tidak melakukan teknik "Shenanigans 7 - Mengalihkan Beban Masa Depan ke Periode Lebih Awal".

\section{PENUTUP}

Brunei Darussalam sebagai negara dengan ukuran geografis kecil yang terletak di bagian utara pulau Kalimantan merupakan negara yang menghasilkan minyak bumi dan gas. Brunei menggunakan dua jenis standar akuntansi dimana yang pertama adalah standar yang diadopsi oleh Brunei yaitu Standar Pelaporan Keuangan Internasional (IFRS) yang berlaku pada tanggal 1 Januari 2014. IFRS dikeluarkan oleh Dewan Standar Akuntansi Internasional 
(IASB) dan digunakan oleh perusahaan yang memiliki kepentingan publik di Brunei. Standar akuntansi kedua adalah Standar Akuntansi Brunei Darussalam (BDAS) yang dikeluarkan oleh BDASC dan berlaku di Brunei mulai dari tanggal 1 Januari 2018.

Financial shenanigans adalah sebuah kejahatan keuangan yang biasanya dilakukan oleh manajemen perusahaan yang berpotensi dalam menyesatkan informasi yang didapatkan investor mengenai kinerja keuangan atau kesehatan ekonomi perusahaan. Dengan analisis yang penulis lakukan berdasarkan laporan tahunan dan laporan keuangan dengan memakai objek Bank Islam Brunei Darussalam (BIBD) selama 5 tahun terakhir, hasil analisa menunjukkan bahwa perusahaan tidak melakukan praktik Shenanigans 1, Shenanigans 2, Shenanigans 4, Shenanigans 5, Shenanigans 6, Shenanigans 7.

Bank Islam Brunei Darussalam (BIBD) melakukan teknik Shenanigans 3 dalam pencatatan laporan keuangannya tanpa pengaruh yang signifikan (jumlah yang kecil) sehingga laporan keuangan masih wajar dan tidak merugikan pihak yang bersangkutan. Hal ini bias dilihat pada Profits from financing, leasing and investments yang dicatat pada laporan jika dibandingkan dengan pencatatan pendapatan atas investasi sangatlah berbeda jauh. Misalnya pencatatan Profits from financing, leasing and investments tahun 2020 sebesar (B\$000) 315,806 dan Gain/(loss) from derivative and investments tahun 2020 sebesar (B\$000) 36,592. Pendapatan atas investasi yang dicatat tidak mempengaruhi angka pendapatan secara signifikan, hanya bagian kecil dari pendapatan saja.

\section{DAFTAR PUSTAKA}

Asim, A., \& Ismail, A. (2019). Impact of Leverage on Earning Management: Empirical Evidence from the Manufacturing Sector of Pakistan. Journal of Finance and Accounting Research, 01(01), 70-91.

https://doi.org/10.32350/jfar.0101.05

BDASC. (2020). Brunei Darussalam Accounting Standards - Non Public Interest Entities (BDAS-NONPIE). (January).

https://bdasc.mofe.gov.bn/SitePages/FAQs-BDAS.aspx

Eye on asian. (2021). Brunei - A country profile. Retrieved May 17, 2021,

https://www.eyeonasia.gov.sg/asean-countries/know/overview-of-asean-countries/brunei-acountry-profile/

Fagbemi, T. O., Osemene, O. F., \& Agbaje, O. (2020). Management Entrenchment, Firm Characteristics and Earnings Management Of Conglomerate Companies In Nigeria. Jurnal Administrasi Bisnis, 9(1), 1.

https://doi.org/10.14710/jab.v9i1.28576

Lamria, F. (2017). Akuntansi Internasional.

http://frischalamria22.blogspot.com/2017/03/akuntansi-internasional.html

Lestari, A. (2017). Perbandingan Sistem Akuntansi Indonesia dengan Brunei Darussalam dan Swedia.

Osunwole, O. O. (2020). Forensic accounting and fraud mitigation in the manufacturing industry in Nigeria. International Journal on Integrated Education, 3(12), 22-29.

https://doi.org/10.31149/ijie.v3i12.884

Primasanti, D. F. S. (2014). Perbandingan Sistem Akuntansi di Indonesia dengan Brunei Darussalam. 
Schilit, H. M. (2010a). Accounting Financial-Shenanigans (pp. 1-20). pp. 1-20.

Schilit, H. M. (2010b). Financial Shenanigans : How to Detect Accounting Gimmicks \& Fraud in Financial Reports. In CFA Institute Conference Proceedings Quarterly.

https://doi.org/10.1080/21551278.1968.9957615

Schilit, H. M. (2010c). Financial Shenanigans: Detecting Accounting Gimmicks That Destroy Investments (corrected November 2010). CFA Institute Conference Proceedings Quarterly, 27(4), 67-74.

https://doi.org/10.2469/cp.v27.n4.1

Tokio Marine Insurance Singapore Ltd, Brunei Darussalam Branch Audited Financial Statements and Other Financial Information (31st December 2018). (2018).

Zsazya. (2020). Standar Akuntansi Keuangan dan Jenisnya yang Berlaku di Indoensia. Online-Pajak.Com. Retrieved from https://www.online-pajak.com/tentang-efiling/standarakuntansi-keuangan\#: :text=Standar akuntansi di Indonesia mengacu,G20 di kawasan Asia Tenggara. 